Published in final edited form as:

Cancer Control. 2013 January ; 20(1): 32-42.

\title{
Immunotherapy for Gastrointestinal Malignancies
}

\author{
Paul G. Toomey, MD, Nasreen A. Vohra, MD, Tomar Ghansah, PhD, Amod A. Sarnaik, MD, \\ and Shari A. Pilon-Thomas, PhD \\ Immunology Program (SAP-T) and the Cutaneous Oncology Program (NAV, AAS) at the H. Lee \\ Moffitt Cancer Center \& Research Institute, Tampa, Florida, and the Departments of Surgery \\ (PGT) and Molecular Medicine (TG), USF Health Morsani College of Medicine at the University of \\ South Florida, Tampa, Florida
}

\begin{abstract}
Background-Gastrointestinal (GI) cancers are the most common human tumors encountered worldwide. The majority of GI cancers are unresectable at the time of diagnosis, and in the subset of patients undergoing resection, few are cured. There is only a modest improvement in survival with the addition of modalities such as chemotherapy and radiation therapy. Due to an increasing global cancer burden, it is imperative to integrate alternative strategies to improve outcomes. It is well known that cancers possess diverse strategies to evade immune detection and destruction. This has led to the incorporation of various immunotherapeutic strategies, which enable reprogramming of the immune system to allow effective recognition and killing of GI tumors.

Methods-A review was conducted of the results of published clinical trials employing immunotherapy for esophageal, gastroesophageal, gastric, hepatocellular, pancreatic, and colorectal cancers.
\end{abstract}

Results-Monoclonal antibody therapy has come to the forefront in the past decade for the treatment of colorectal cancer. Immunotherapeutic successes in solid cancers such as melanoma and prostate cancer have led to the active investigation of immunotherapy for GI malignancies, with some promising results.

Conclusions-To date, monoclonal antibody therapy is the only immunotherapy approved by the US Food and Drug Administration for GI cancers. Initial trials validating new immunotherapeutic approaches, including vaccination-based and adoptive cell therapy strategies, for GI malignancies have demonstrated safety and the induction of antitumor immune responses. Therefore, immunotherapy is at the forefront of neoadjuvant as well as adjuvant therapies for the treatment and eradication of GI malignancies.

Address correspondence to Shari A. Pilon-Thomas, PhD, Immunology Program, Moffitt Cancer Center, 12902 Magnolia Drive, SRB-2, Tampa, FL 33612. Shari.Pilon-Thomas@ Moffitt.org.

No significant relationship exists between the authors and the companies/organizations whose products or services may be referenced in this article.

Appreciation is expressed to our colleagues Gregory Springett, $\mathrm{MD}, \mathrm{PhD}$, and Mokenge Malafa, $\mathrm{MD}$, for their collaborative efforts to bring modern immunotherapeutic treatments into the realm of GI malignancies. 


\section{Introduction}

Gastrointestinal (GI) cancers are the most common human tumors encountered worldwide. ${ }^{1}$ Surgical resection continues to be the primary curative treatment for the majority of GI cancers, although a large proportion of patients are unresectable at the time of diagnosis. For patients who undergo resection alone, the overall 5-year survival rate remains poor. The addition of neoadjuvant or adjuvant chemotherapy and radiation therapy only modestly improves the overall long-term survival. ${ }^{2-9}$ With the exception of colon cancer, no efficacious screening methods currently are available for most GI malignancies, resulting in diagnosis at an advanced stage. Therefore, it is imperative to develop not only effective screening modalities but also effective treatments for patients who have advanced unresectable disease in order to downstage it to resectable disease or improve disease control.

Although immunotherapeutic approaches have been extensively promoted in other cancers such as melanoma and renal cell carcinoma, the potential use of immune-based therapy to treat advanced GI malignancies is just being realized. It is known that tumor-specific T cells can be isolated from patients with GI cancers. ${ }^{10-14}$ Infiltration of T cells into GI tumors correlates with improved prognosis in several types of GI cancers. ${ }^{15-20}$ The presence of negative regulatory factors, such as regulatory $\mathrm{T}$ cells and myeloid-derived suppressor cells, which can inhibit antitumor T-cell responses, correlates with a poor prognosis in several GI cancers. $^{21-23}$ With the identification of tumor-associated antigens on GI tumors, as shown in Table $1,{ }^{24-37}$ strategies to target these antigens are currently being developed. Although multiple approaches to induce immunity against GI malignancies have been tested, this article focuses on the use of monoclonal antibodies, adoptive cell transfer, and vaccinebased immunotherapy for GI cancers (Figure).

\section{Immunotherapeutic Strategies for GI Malignancies}

\section{Monoclonal Antibody Therapy}

Monoclonal antibodies (mAbs) are used to target specific antigens expressed on tumor cells. Some of the mechanisms of action of mAb therapy include blocking growth factor/receptor interactions, down-regulating proteins required for tumor growth, and activating effector mechanisms of the immune system (including complement-dependent cytotoxicity and antibody-dependent cell-mediated cytotoxicity [ADCC]). Unlike conventional chemotherapy, which affects mitotically active normal cells in addition to neoplastic cells, $\mathrm{mAb}$ therapy has the distinct potential advantage of tumor antigen-specific recognition and therefore fewer and less severe adverse effects compared with cytotoxic therapy. Antibodies can be readily produced in large quantities for easy implementation and can be used in all patients who express the specific antigen on their tumor. Currently, mAb therapy is the most utilized immunotherapy for GI cancers; to date, the US Food and Drug Administration (FDA) has approved four mAb therapies targeting GI malignancies: bevacizumab, cetuximab, panitumumab, and trastuzumab (Table 2).

Immunomodulatory $\mathrm{mAb}$ therapies directly target immune cells, as opposed to tumor antigens. Ipilimumab is a mAb that blocks cytotoxic T-lymphocyte antigen-4 (CTLA-4) on 
the surface of $\mathrm{T}$ cells, leading to increased numbers of activated T cells. ${ }^{38}$ Ipilimumab has shown efficacy in inducing clinical responses and has been approved by the FDA for patients with metastatic melanoma. ${ }^{39}$ Blocking the programmed death-1 (PD-1) receptor on activated $\mathrm{T}$ cells with $\mathrm{mAbs}$ has been shown to overcome immune resistance and induce clinical responses in patients with solid tumors. ${ }^{40}$ These and other novel immunomodulatory $\mathrm{mAb}$ therapies are currently being explored for GI malignancies.

\section{Cancer Vaccines}

The goals of cancer vaccination are to activate and expand tumor-specific $\mathrm{T}$ cells as effective means of augmenting immunity. To induce a robust antitumor immune response, peptides derived from tumor-associated antigens must be presented to T cells. Effective vaccination requires these peptides to be presented by a professional antigen-presenting cell, such as a dendritic cell (DC). Immature DCs reside in peripheral tissues, where they take up and process antigens. Within the DCs, antigens are targeted to the proteasomal or endocytic pathway, degraded to peptides, and bound to major histocompatibility complex (MHC) class I molecules for presentation to $\mathrm{CD} 8^{+}$cytotoxic $\mathrm{T}$ cells or to MHC class II molecules for presentation to $\mathrm{CD} 4^{+}$helper $\mathrm{T}$ cells. As immature DCs acquire antigen at the site of vaccination, they may come into contact with immune-stimulating adjuvants or activated $\mathrm{T}$ cells, which induce full maturation of DCs and migration to draining lymph nodes. Mature DCs demonstrate diminished antigen uptake but upregulate costimulatory molecules for enhanced interaction with $\mathrm{T}$ cells. Within the lymph nodes, DCs educate naive T cells for the stimulation of primary antitumor responses and induction of immunologic memory. Activated $\mathrm{T}$ cells migrate to the site of antigen expression, the tumor, to exert effector functions such as cell cytotoxicity and inflammatory cytokine production. Such activity results in tumor regression.

Therapeutic vaccinations are designed to enhance preexisting immunity or induce novel, robust antitumor immune responses in patients with cancer. Vaccine strategies have included the use of peptides derived from tumor-associated antigens, whole tumor cells, tumor-associated antigen-encoding DNA, or viral vectors alone or with in vitro generated DCs. DCs are the most potent antigen-presenting cells, capable of activating naive and memory T cells. ${ }^{41}$

Tumor antigen-pulsed DC-based vaccines have been shown to induce both $\mathrm{CD} 8^{+}$and $\mathrm{CD} 4^{+}$ T-cell responses in patients with advanced cancers. ${ }^{42}$ Although clinical trials using DCbased vaccines in patients with advanced cancers have led to positive immunologic endpoints, few clinical responses have been seen. ${ }^{43-45}$ One exception is the use of sipuleucel-T.

Sipuleucel-T is a DC-containing cellular vaccine loaded with a fusion protein of prostatic acid phosphatase and granulocyte macrophage-colony stimulating factor (PAP-GM-CSF) and has been shown to increase overall survival (OS) in patients with metastatic prostate cancer. ${ }^{46}$ Sipuleucel-T is the first therapeutic cancer vaccine to receive FDA approval and has raised the potential for the use of DC-based vaccines in other cancers, including GI tumors. 


\section{Adoptive Cell Therapy}

Adoptive cell therapy is the passive transfer of tumor-specific T cells into a tumor-bearing host for the direct destruction of tumors. Unlike mAb therapy, adoptive cell therapies are "personalized" for each patient. The discovery of interleukin-2 (IL-2) as a critical T-cell growth factor allowed for the expansion of large numbers of $\mathrm{T}$ cells ex vivo.

The first clinical trial of adoptive cell therapy in patients with advanced cancers was the transfer of lymphokine-activated killer (LAK) cells. ${ }^{47}$ LAK cells were generated by culturing peripheral lymphocytes in high concentrations of IL-2 that resulted in the generation of cytotoxic cells, which could directly lyse tumor cells. Since then, strategies to isolate and expand tumor antigen-specific T cells have been developed. Adoptive cell therapy with autologous tumor-infiltrating lymphocytes (TILs) takes advantage of lymphocytes that have demonstrated the ability to home to the tumor. Adoptive cell therapy with TILs isolated from resected tumors, expanded ex vivo, and administered to patients in combination with IL-2 has demonstrated a $50 \%$ response in patients with metastatic melanoma. ${ }^{48-51}$ This approach is currently under investigation for the treatment of nonmelanoma tumors. TILs have been isolated from a variety of GI tumors and may be a promising new approach for patients with metastatic GI cancers. ${ }^{52}$

\section{Immunotherapeutic Approaches to GI Malignancies \\ Colorectal Cancer}

Colorectal cancer (CRC) is the third most common cancer and the fourth most common cause of cancer deaths worldwide. ${ }^{53,54}$ Colon cancer mortality is decreasing in the United States, with colon cancer screening being the most important contributing factor. ${ }^{54}$ Despite these successes, half of patients with CRC will develop metastases. ${ }^{55}$ Historically, the median survival of patients with metastatic CRC not amenable to surgery is 6 to 12 months. ${ }^{55}$ Survival significantly improves if the patient has resectable metastatic disease, with a 5 -year survival rate of $26 \%$ to $40 \% .^{55}$

Colon cancer is one of the few GI cancers with existing FDA-approved immunotherapy. Cetuximab is a mAb that directly inhibits the epidermal growth factor receptor (EGFR). ${ }^{56}$ There is evidence that cetuximab also mediates ADCC. ${ }^{57}$ Cetuximab was first approved by the FDA in early 2004 for patients with metastatic CRC in combination with irinotecan. Rates of response and time to tumor progression for the combination were superior with cetuximab to irinotecan alone. ${ }^{58}$ In 2007, cetuximab as monotherapy was approved for patients with EGFR-expressing metastatic CRC after both irinotecan- and oxaliplatin-based chemotherapy regimens failed.

In mid-2004, bevacizumab was approved as first-line therapy for metastatic CRC in combination with 5-fluorouracil (5-FU), leucovorin, and irinotecan (FOL-FIRI). ${ }^{59}$ Bevacizumab is a mAb that inhibits angiogenesis by directly targeting the vascular endothelial growth factor (VEGF) protein. ${ }^{60}$ In 2006, bevacizumab was approved by the FDA as second-line therapy for metastatic CRC in combination with 5-FU, leucovorin, and oxaliplatin (FOLFOX). The combination resulted in a significantly improved survival when bevacizumab was added to the regimen. ${ }^{61}$ 
Panitumumab, another EGFR inhibitor, was approved by the FDA in 2006 for patients with EGFR-expressing metastatic CRC. Panitumumab has been shown to mediate ADCC through myeloid-derived granulocytes. ${ }^{62}$ Patients with EGFR-expressing tumor cells were found to have significant benefit in progression-free survival (PFS) when panitumumab was added to a FOLFIRI regimen. ${ }^{63,64}$ A subsequent randomized phase III trial also showed a significant improvement of PFS with panitumumab and FOLFOX therapy. ${ }^{65}$

An initial clinical trial has raised the potential for immunomodulatory mAb therapy for CRC. In a phase I study, treatment with anti-PD-1 antibody led to a complete response in a patient with metastatic CRC. ${ }^{66}$ Further studies are warranted to determine whether targeting immune cells will improve the treatment of CRC.

Autologous tumor-based vaccination has led to successes in the treatment of CRC. The National Surgical Adjuvant Breast and Bowel Project (NSABP) C-01 phase III trial demonstrated that postoperative therapy with the immunostimulating adjuvant bacillus Calmette Guérin (BCG) led to a significantly improved OS in patients with resected Dukes' stage $\mathrm{B}$ or $\mathrm{C}$ colon adenocarcinoma. ${ }^{67}$ After a 10 -year follow-up, the authors concluded that there was no difference in disease-free survival but a statistically significant increase in OS for patients who received BCG, whereas chemotherapy did not portend a survival benefit. ${ }^{67}$ Combining BCG with an autologous tumor cell vaccine, currently in phase III trials, has been shown to increase disease-free survival and OS in patients with resected stage II/III colorectal adenocarcinoma. ${ }^{68-70}$ Another cell-based vaccine for the treatment of CRC involves Newcastle disease virus (NDV) infected autologous tumor cells; in a phase III clinical trial, patients with colon cancer demonstrated increased metastasis-free survival and OS with this vaccine. ${ }^{71,72}$

Carcinoembryonic antigen (CEA) is a tumor-associated antigen expressed by most CRCs and has been one of the most popular targets for vaccine-based immunotherapeutic strategies. DNA vaccination with plasmid coexpressing the CEA and hepatitis B surface antigen ( $\mathrm{HbsAg}$ ) genes demonstrated positive immunologic responses to both CEA and HbsAg in patients with metastatic CRC. ${ }^{34}$ Unfortunately, no objective tumor responses were observed in this study.

Viral-based vaccinations using fowlpox and vaccinia viruses encoding the CEA antigen and TRICOM (B7.1, ICAM-1, and LFA-3) demonstrated induction of anti-CEA-specific T-cell responses and stable disease in $40 \%$ of patients with metastatic cancer, including CRC. ${ }^{35} \mathrm{~A}$ phase II clinical trial in patients with metastatic CRC examined combination chemotherapy and vaccination with a canary pox virus encoding CEA and the T-cell costimulatory molecule CD80 (ALVAC-CEA/ B7.1). The trial demonstrated that anti-CEA-specific T-cell responses could be successfully generated in patients undergoing chemotherapy. Objective clinical responses were observed in $40 \%$ of the patients. ${ }^{36,37}$

Early-phase clinical trials have been undertaken to determine the efficacy of DC-based therapy. Patients with advanced CRC were vaccinated with DCs pulsed with CEA peptides $^{73-76}$ or CEA mRNA. ${ }^{76,77}$ The majority of patients demonstrated positive CEAspecific T-cell responses after vaccination, and induction of stable disease was determined in 
several patients. Together, these trials have demonstrated the safety of vaccine-based strategies and have shown positive immunologic and clinical endpoints.

Although infiltrating $\mathrm{T}$ cells are correlated with an improved prognosis, relatively few adoptive cell therapy trials for the treatment of CRC have been performed. ${ }^{78}$ In a phase I clinical trial, 14 patients with resected metastatic CRC received adoptive cell therapy with TILs in combination with high-dose IL-2. ${ }^{79}$ Although persistence of adoptively transferred $\mathrm{T}$ cells correlated with disease-free survival, there was no statistical difference between patients treated with TILs and those treated with traditional chemotherapy regarding diseasefree survival. In another pilot study, T cells were expanded from the tumor-draining sentinel lymph nodes and reinfused back into patients with disseminated or locally advanced CRC. Four of 9 patients experienced a complete response ${ }^{80}$ Although data supporting immunotherapy for CRC are the most mature for all GI malignancies, there is ample opportunity for further clinical investigation.

\section{Esophageal Cancer}

Esophageal cancer is the eighth most common cancer worldwide. ${ }^{53,81}$ The two most common types are squamous cell carcinoma (SCC), with a higher incidence worldwide, and adenocarcinoma, which has a higher incidence in the United States. Five-year OS rates after resection are $20 \%$ to $30 \%$ and $20 \%$ to $25 \%$, respectively. ${ }^{82}$ The incidence of esophageal cancer is rising in the Western world secondary to an increase in esophageal adenocarcinoma. ${ }^{81}$

As overexpression of EGFR in esophageal cancer has been correlated with a poor prognosis, $\mathrm{mAb}$ therapy to target the EGFR signaling pathway is currently being tested in esophageal cancer. ${ }^{83,84}$ The efficacy of cetuximab for the treatment of patients with esophageal adenocarcinoma or SCC has yet to be established in prior and ongoing clinical trials. Additional trials to examine mAb therapy with cetuximab and trastuzumab alone or in combination with radiation or chemotherapy have been performed (Table $3^{85-88}$ and Table $\left.4^{89-95}\right)$.

Data involving the use of vaccine-based or adoptive cell transfer immunotherapy for esophageal carcinoma are scarce. A phase I trial was reported with a peptide vaccine administered to 10 patients with stage III or IV esophageal SCC whose disease had progressed on conventional treatment, with 1 complete response and stable disease in 3 patients. ${ }^{96}$ The peptides were derived from three novel HLA-A24-restricted cancer-testis antigen peptides, and peptide-specific T-cell responses were detected in 9 of 10 patients after vaccination.

To date, only one phase I/II trial has been conducted for esophageal SCC with adoptive cell therapy. ${ }^{97}$ Peripheral blood mononuclear cells were stimulated in vitro with autologous tumor cells. T cells were directly injected into primary tumors, metastatic lymph nodes, pleural spaces, or ascites in combination with intravenous IL-2. The authors reported objective tumor responses in half of the patients. Four of 11 patients (36\%) had confirmed complete or partial responses. The same group published a case report of another patient with recurrent esophageal SCC who had a partial response to the same therapy. ${ }^{98}$ Additional 
trials are required to determine the efficacy of vaccine and T-cell-based therapies for esophageal carcinoma.

\section{Gastroesophageal Junction Adenocarcinoma/ Gastric Adenocarcinoma}

Over the past few decades, gastric cancer mortality has dropped significantly, but it remains a disease with a poor prognosis and high mortality. ${ }^{99}$ Gastric cancer is the fourth most common cancer and the second leading cause of cancer deaths worldwide. ${ }^{54,99}$ Gastric cancer portends a 5 -year survival rate of less than $20 \% .100$

A phase III, multinational, randomized, placebo-controlled trial has been undertaken with bevacizumab. ${ }^{101}$ As previously discussed, bevacizumab is a mAb that prevents angiogenesis by directly targeting the VEGF protein. Patients who received the combination of bevacizumab, capecitabine, and cisplatin were found to have a significantly improved PFS and objective response rate compared with patients treated with capecitabine and cisplatin alone.

Human epidermal growth factor receptor (HER2/ neu) overexpression has been found in gastric and gastroesophageal junction adenocarcinoma. ${ }^{26,27}$ Trastuzumab is a humanized mAb against HER2 and was recently used in phase III trials for patients with HER2/neupositive, locally advanced and/or metastatic gastric or gastroesophageal adenocarcinoma. ${ }^{102,103}$ Patients with HER2/neu-positive gastroesophageal or gastric adenocarcinoma had significantly improved OS with trastuzumab in combination with chemotherapy compared with patients who underwent chemotherapy alone. With these promising results, trastuzumab gained FDA approval in 2010 for the treatment of HER2positive gastric or gastroesophageal junction adenocarcinoma.

HER2/neu overexpression in gastric cancer has also been explored for DC therapy. Patients with advanced gastric cancer were treated with DCs pulsed with HER2/neu-derived peptides in a phase I trial. ${ }^{104}$ The vaccine was found to be safe and efficacious at inducing tumorspecific T-cell responses, with 2 of 9 patients exhibiting an objective clinical response.

Adoptive cell therapy has also had some success in patients with gastric cancer. In a nonrandomized trial, patients treated with oxaliplatin combined with adoptive cell therapy with cytokine-induced killer cells produced from peripheral blood mononuclear cells had increased survival compared with those who received oxaliplatin alone. ${ }^{105}$

In a randomized trial, patients with gastric cancer treated with cisplatin/5-FU in combination therapy with tumor-associated lymphocytes purified from ascites, pleural fluid, and/or lymph nodes demonstrated an increased survival compared with those treated with chemotherapy alone. ${ }^{106}$ Similar to esophageal cancer, targeted immunotherapy for gastric cancer is the most established modality, with alternative immunotherapies currently being explored.

\section{Hepatocellular Cancer}

Hepatocellular carcinoma (HCC) is a leading cause of cancer-related death worldwide. The incidence is particularly high in Asia and sub-Saharan Africa, but the incidence of HCC is 
climbing in North America and Europe. ${ }^{107}$ The incidence in the United States has been increasing for the past two decades. ${ }^{108}$ Over $70 \%$ of patients are not candidates for surgical resection and/or liver transplantation. These limitations are typically due to impaired liver function secondary to cirrhosis or a prohibitively high tumor burden. ${ }^{109}$ Some success has been reported with mAb therapy in HCC. In phase II studies, bevacizumab has been used in combination with targeted therapy, yielding a significant increase in PFS compared with historic controls. ${ }^{110}$ Levels of alpha-fetoprotein (AFP) are elevated in the serum of the majority (50\% to $80 \%$ ) of patients with HCC. ${ }^{32}$ This marker has been exploited for DCbased vaccination therapy.

A phase I/II trial examined vaccination of patients with HCC with DCs pulsed with four AFP-derived peptides. ${ }^{111}$ Six of 10 patients demonstrated positive T-cell responses to AFP after vaccinations. In another trial, DCs pulsed with autologous tumor cells resulted in $68 \%$ of patients achieving stable disease or partial response and an increase in OS. The subset of patients who received monthly booster DC vaccines had a robust response, with 1-year survival rates increased over 50 months compared with those who received DC-pulsed therapy alone. ${ }^{112}$

In a phase II study of patients with advanced HCC, patients received intravenous vaccination with DCs pulsed with lysate derived from the HepG2 liver tumor cell line. ${ }^{113} \mathrm{~A}$ partial response or stable disease was measured in $28 \%$ of patients. In a phase I trial, autologous immature DCs were injected intratumorally after radiation therapy and were able to induce tumor-specific and innate immunity, with only 5 of 14 patients (38\%) having progressive disease. ${ }^{114}$ Adjuvant tumor lysate vaccines after partial hepatectomy have been shown to decrease recurrence and increase overall and recurrence-free survival rates in phase II studies. ${ }^{115,116} \mathrm{~A}$ few adoptive cell therapy trials have been performed in patients with resected HCC. Early studies examined the efficacy of adoptive transfer of IL-2activated LAK cells in combination with doxorubicin, which decreased recurrence in patients with resected HCC. ${ }^{117}$ Another adoptive cell therapy trial utilizing TILs in combination with high-dose IL-2 demonstrated a decrease in disease recurrence in patients with resected HCC compared with historic controls. ${ }^{118}$ Multiple infusions of intravenous peripheral blood lymphocytes stimulated ex vivo with IL-2 and anti-CD3 decreased recurrence and increased recurrence-free survival but did not significantly increase OS in patients with resected HCC. ${ }^{10}$ Immunotherapeutic approaches have been most extensively investigated for HCC, with adoptive transfer and vaccine-based therapies limited to investigational reports and early-phase clinical trials.

\section{Pancreatic Cancer}

Pancreatic cancer is the fourth leading cause of cancer death in the United States and has the highest fatality rate worldwide. ${ }^{54}$ The overwhelming majority of patients with pancreatic adenocarcinoma have locally advanced and/or metastatic disease at the time of presentation, thereby precluding any prospect of complete tumor extirpation. ${ }^{19-121}$ Complete tumor resection for pancreatic adenocarcinoma is the only chance for long-term survival. ${ }^{122-126}$ Patients who undergo pancreatic resection for pancreatic adenocarcinoma portend a 5-year survival rate of up to $20 \% .^{127,128}$ Treatment with chemotherapy, including gemcitabine and 
FOLFIRINOX (5-FU, leucovorin, irinotecan, oxaliplatin), results in a median OS of 6.8 months and 11.1 months, respectively, for patients with unresectable pancreatic cancer. ${ }^{129}$

Unlike with other GI malignancies, mAb therapy has shown little efficacy for the treatment of pancreatic cancer. In separate phase III trials, cetuximab or bevacizumab in combination with gemcitabine did not significantly improve the response rate, PFS, or OS when compared with gemcitabine alone. ${ }^{130,131}$ Ipilimumab is currently being investigated for patients with pancreatic adenocarcinoma. In a study of 27 patients, delayed tumor regression was observed in 1 patient treated with ipilimumab. ${ }^{132}$ Treatment with the agonist CD40 $\mathrm{mAb}$, a novel therapy that activates antigen-presenting cells, in combination with gemcitabine therapy led to partial responses in 4 of 21 patients. ${ }^{133}$

Whole-cell vaccine-based therapies have been explored for the treatment of pancreatic cancer in resected patients. Antimesothelin immunity has been measured in patients with pancreatic cancer. ${ }^{31}$ Vaccination with GM-CSF-secreting tumor cells led to the induction of mesothelin-specific T-cell responses, which correlated with disease-free survival. ${ }^{134,135}$ Algenpantucel-L is an irradiated allogeneic human pancreatic cancer cell line that expresses the murine enzyme a-1,3 galactosyl transferase to induce a hyperacute immunologic response. This study was based on impressive phase II data in which survival at 12 and 24 months was improved to $91 \%$ and 54\%, respectively, when compared with expected survival of $63 \%$ and $32 \%$, respectively. ${ }^{136}$ A phase III trial examining combination therapy with gemcitabine, 5-FU-radiation, and algenpantucel-L after resection of pancreatic adenocarcinoma is currently ongoing.

Several DC-based vaccine trials for pancreatic cancer have been performed. In patients with locally advanced and metastatic melanoma, intratumoral injection of DCs in combination with an adenovector containing the gene for tumor necrosis factor- $a$ and radiation has led to tumor regression in 2 patients, which correlated with immune reactivity and enhanced T-cell infiltration into tumors. ${ }^{137}$ In patients with resected pancreatic cancer, a phase I clinical trial examining mucin-1 (MUC1) peptide-pulsed DCs led to long-term survival in 4 of 12 patients. ${ }^{28,29}$

Little has been done with adoptive cell therapy for the treatment of pancreatic cancer. ${ }^{138}$ Peripheral blood mononuclear cells from patients with pancreatic cancer were stimulated in vitro with MUC1-expressing tumor cell lines to generate cytotoxic T lymphocytes. Transfer of these $\mathrm{T}$ cells led to enhanced survival in resected patients compared with historic controls receiving surgery alone. ${ }^{139}$ In another trial by the same group, 20 patients with unresectable or recurrent pancreatic cancer were treated with MUC1-specific lymphocytes in combination with MUC1 peptide-pulsed DC vaccination. This therapy led to 1 complete response and induction of stable disease in 5 patients. ${ }^{140}$

Although infiltration of $\mathrm{T}$ cells can be measured in the tumors of patients with pancreatic cancer, ${ }^{138}$ transfer of ex vivo-expanded TILs is still in preclinical development. Ongoing work in our laboratory is examining the feasibility of isolating and expanding tumorinfiltrating $\mathrm{T}$ cells for use in an adoptive cell therapy trial. 


\section{Conclusions}

Immunotherapy is an emerging modality for the treatment of gastrointestinal (GI) cancers. Although monoclonal antibody $(\mathrm{mAb})$ therapy comprises a significant proportion of immunotherapies for GI cancers, early clinical trials have demonstrated the safety and feasibility of vaccine-based strategies to induce positive immunologic endpoints in patients with GI cancers. As more knowledge of the human genome and molecular interactions is gained, the number of GI tumor-associated specific antigens that can be potentially targeted by $\mathrm{mAb}$ therapy and vaccination is increasing. We believe there will be many subsequent studies investigating the effects of $\mathrm{mAb}$ and vaccine-based therapies alone or in combination with other immunotherapeutic strategies.

Colorectal cancer could be the prototypic cancer for which successful immunotherapy of other GI malignancies is based. To date, three discrete $\mathrm{mAb}$ regimens have been successfully used. These successes may result in combination antibody therapies and the potential for further novel therapies for this disease. Furthermore, the autologous tumor cell with the bacillus Calmette Guérin (BCG) vaccine is being investigated in the phase III setting for stage II/III colorectal adenocarcinoma.

For esophageal, gastroesophageal, and gastric cancers, many mAb therapies have been tested, with some promising data. The approval of trastuzumab in 2010 marked the first immunotherapy approved for any of the upper GI tumors. For patients with esophageal, gastroesophageal, and gastric cancer, multiple ongoing trials will determine whether combination $\mathrm{mAb}$ therapy with chemotherapy or radiation therapy increases overall survival. Although advanced esophageal, gastric, and gastroesophageal cancers continue to have poor prognoses, the incremental gains achieved with these mAb-based immunologic approaches combined with the potential for vaccine or cell-based immunotherapy are encouraging.

Pancreatic cancer continues to be a fatal disease, despite the application of novel immunotherapies. The use of mAb therapy has not yielded significant improvements in the outcome of unresectable pancreatic cancer. However, novel approaches have raised the potential for the use of immunotherapy for pancreatic cancer. Vaccine-based immunotherapies using whole tumor cells or dendritic cells have been shown to enhance antitumor cell responses and improve responses in patients with advanced pancreatic cancer.

This is an exciting time for immunotherapy in GI cancers. Additional novel and exciting immunostimulatory $\mathrm{mAb}$ therapies are under investigation for GI malignancies. We believe that early successes will lead to the optimization of vaccination approaches and the determination of the most effective vaccination strategy and most beneficial tumorassociated antigens for the treatment of resected or advanced GI cancers. Development of adoptive cell therapies for GI cancers is underway and may provide a promising new therapeutic modality in the future. As our understanding of suppressive factors in patients with GI cancers increases, new strategies to decrease immune suppression and enhance endogenous immunity in patients with GI cancers are being developed. Together, we believe that advances in immunology, increased knowledge of the tumor microenvironment, and 
prior successes will drive clinicians and researchers alike to achieve practical and effective immunotherapeutic strategies.

\section{References}

1. Jemal A, Siegel R, Ward E, et al. Cancer statistics, 2009. CA Cancer J Clin. 2009; 59(4):225-249. [PubMed: 19474385]

2. Pöttgen C, Stuschke M. Radiotherapy versus surgery within multimodality protocols for esophageal cancer: a meta-analysis of the randomized trials. Cancer Treat Rev. 2012; 38(6):599-604. [PubMed: 22116018]

3. Cunningham D, Allum WH, Stenning SP, et al. Perioperative chemotherapy versus surgery alone for resectable gastroesophageal cancer. N Engl J Med. 2006; 355(1):11-20. [PubMed: 16822992]

4. Artinyan A, Anaya DA, McKenzie S, et al. Neoadjuvant therapy is associated with improved survival in resectable pancreatic adenocarcinoma. Cancer. 2011; 117(10):2044-2049. [PubMed: 21523715]

5. Winter JM, Brennan MF, Tang LH, et al. Survival after resection of pancreatic adenocarcinoma: results from a single institution over three decades. Ann Surg Oncol. 2012; 19(1):169-175. [PubMed: 21761104]

6. Sargent D, Sobrero A, Grothey A, et al. Evidence for cure by adjuvant therapy in colon cancer: observations based on individual patient data from 20,898 patients on 18 randomized trials. J Clin Oncol. 2009; 27(6):872-877. [PubMed: 19124803]

7. Gong Z, Holly EA, Bracci PM. Survival in population-based pancreatic cancer patients: San Francisco Bay area, 1995-1999. Am J Epidemiol. 2011; 174(12):1373-1381. [PubMed: 22047824]

8. Winter JM, Cameron JL, Campbell KA, et al. 1423 pancreaticoduodenectomies for pancreatic cancer: a single-institution experience. J Gastrointest Surg. 2006; 10(9):1199-1211. [PubMed: 17114007]

9. Luo Y, Cui J, Chen C, et al. Clinical outcomes after surgical resection of colorectal cancer in 1,294 patients. Hepatogastroenterology. 2012; 59(117):1398-1402. [PubMed: 22115801]

10. Takayama T, Sekine T, Makuuchi M, et al. Adoptive immunotherapy to lower postsurgical recurrence rates of hepatocellular carcinoma: a randomised trial. Lancet. 2000; 356(9232):802807. [PubMed: 11022927]

11. Kono K, Ichihara F, Iizuka H, et al. Differences in the recognition of tumor-specific CD8+ T cells derived from solid tumor, metastatic lymph nodes and ascites in patients with gastric cancer. Int $\mathrm{J}$ Cancer. 1997; 71(6):978-981. [PubMed: 9185700]

12. Ikeda H, Sato N, Matsuura A, Kikuchi K. Analysis of T-cell receptor V region gene usage of cytotoxic T-lymphocytes and tumor-infiltrating lymphocytes derived from human autologous gastric signet ring cell carcinomas. Cancer Res. 1993; 53(13):3078-3084. [PubMed: 8391386]

13. Amedei A, Niccolai E, Della Bella C, et al. Characterization of tumor antigen peptide-specific $\mathrm{T}$ cells isolated from the neoplastic tissue of patients with gastric adenocarcinoma. Cancer Immunol Immunother. 2009; 58(11):1819-1830. [PubMed: 19319530]

14. Schmitz-Winnenthal FH, Volk C, Z'graggen K, et al. High frequencies of functional tumorreactive $T$ cells in bone marrow and blood of pancreatic cancer patients. Cancer Res. 2005; 65(21): 10079-10087. [PubMed: 16267034]

15. Gooden MJ, de Bock GH, Leffers N, et al. The prognostic influence of tumour-infiltrating lymphocytes in cancer: a systematic review with meta-analysis. Br J Cancer. 2011; 105(1):93-103. [PubMed: 21629244]

16. Nosho K, Baba Y, Tanaka N, et al. Tumour-infiltrating T-cell subsets, molecular changes in colorectal cancer, and prognosis: cohort study and literature review. J Pathol. 2010; 222(4):350366. [PubMed: 20927778]

17. Katz SC, Donkor C, Glasgow K, et al. T cell infiltrate and outcome following resection of intermediate-grade primary neuroendocrine tumours and liver metastases. HPB (Oxford). 2010; 12(10):674-683. [PubMed: 21083792] 
18. Kitayama J, Atomi Y, Nagawa H, et al. Functional analysis of TCR gamma delta+ T cells in tumour-infiltrating lymphocytes (TIL) of human pancreatic cancer. Clin Exp Immunol. 1993; 93(3):442-447. [PubMed: 8370173]

19. Deschoolmeester V, Baay M, Van Marck E, et al. Tumor infiltrating lymphocytes: an intriguing player in the survival of colorectal cancer patients. BMC Immunol. 2010; 11:19. [PubMed: 20385003]

20. Pagès F, Kirilovsky A, Mlecnik B, et al. In situ cytotoxic and memory T cells predict outcome in patients with early-stage colorectal cancer. J Clin Oncol. 2009; 27(35):5944-5951. [PubMed: 19858404]

21. Gabitass RF, Annels NE, Stocken DD, et al. Elevated myeloid-derived suppressor cells in pancreatic, esophageal and gastric cancer are an independent prognostic factor and are associated with significant elevation of the Th2 cytokine interleukin-13. Cancer Immunol Immunother. 2011; 60(10):1419-1430. [PubMed: 21644036]

22. Mundy-Bosse BL, Young GS, Bauer T, et al. Distinct myeloid suppressor cell subsets correlate with plasma IL-6 and IL-10 and reduced interferon-alpha signaling in $\mathrm{CD}^{+}{ }^{+} \mathrm{T}$ cells from patients with GI malignancy. Cancer Immunol Immunother. 2011; 60(9):1269-1279. [PubMed: 21604071]

23. Chen W, Perruche S, Li J. CD4+CD25+ T regulatory cells and TGF-beta in mucosal immune system: the good and the bad. Curr Med Chem. 2007; 14(21):2245-2249. [PubMed: 17896973]

24. Bujas T, Marusic Z, Peric Balja M, et al. MAGE-A3/4 and NY-ESO-1 antigens expression in metastatic esophageal squamous cell carcinoma. Eur J Histochem. 2011; 55(1):e7. [PubMed: 21556122]

25. Forghanifard MM, Gholamin M, Farshchian M, et al. Cancer-testis gene expression profiling in esophageal squamous cell carcinoma: identification of specific tumor marker and potential targets for immunotherapy. Cancer Biol Ther. 2011; 12(3):191-197. [PubMed: 21613820]

26. Ross JS, McKenna BJ. The HER-2/neu oncogene in tumors of the gastrointestinal tract. Cancer Invest. 2001; 19(5):554-568. [PubMed: 11458821]

27. Ross JS. Update on HER2 testing for breast and upper gastrointestinal tract cancers. Biomark Med. 2011; 5(3):307-318. [PubMed: 21657840]

28. Lepisto AJ, Moser AJ, Zeh H, et al. A phase I/II study of a MUC1 peptide pulsed autologous dendritic cell vaccine as adjuvant therapy in patients with resected pancreatic and biliary tumors. Cancer Ther. 2008; 6(B):955-964. [PubMed: 19129927]

29. Pecher G, Haring A, Kaiser L, Thiel E. Mucin gene (MUC1) transfected dendritic cells as vaccine: results of a phase I/II clinical trial. Cancer Immunol Immunother. 2002; 51(11-12):669-673. [PubMed: 12439613]

30. Li M, Bharadwaj U, Zhang R, et al. Mesothelin is a malignant factor and therapeutic vaccine target for pancreatic cancer. Mol Cancer Ther. 2008; 7(2):286-296. [PubMed: 18281514]

31. Johnston FM, Tan MC, Tan BR Jr, et al. Circulating mesothelin protein and cellular antimesothelin immunity in patients with pancreatic cancer. Clin Cancer Res. 2009; 15(21):6511-6518. [PubMed: 19843662]

32. Butterfield LH. Immunotherapeutic strategies for hepatocellular carcinoma. Gastroenterology. 2004; 127(5 suppl 1):S232-S241. [PubMed: 15508089]

33. Evdokimova VN, Butterfield LH. Alpha-fetoprotein and other tumour-associated antigens for immunotherapy of hepatocellular cancer. Expert Opin Biol Ther. 2008; 8(3):325-336. [PubMed: 18294103]

34. Conry RM, Curiel DT, Strong TV, et al. Safety and immunogenicity of a DNA vaccine encoding carcinoembryonic antigen and hepatitis B surface antigen in colorectal carcinoma patients. Clin Cancer Res. 2002; 8(9):2782-2787. [PubMed: 12231517]

35. Marshall JL, Gulley JL, Arlen PM, et al. Phase I study of sequential vaccinations with fowlpoxCEA(6D)-TRICOM alone and sequentially with vaccinia-CEA(6D)-TRICOM, with and without granulocyte-macrophage colony-stimulating factor, in patients with carcinoembryonic antigenexpressing carcinomas. J Clin Oncol. 2005; 23(4):720-731. [PubMed: 15613691]

36. Kaufman HL, Lenz HJ, Marshall J, et al. Combination chemotherapy and ALVAC-CEA/B7.1 vaccine in patients with metastatic colorectal cancer. Clin Cancer Res. 2008; 14(15):4843-4849. [PubMed: 18676757] 
37. Hörig H, Lee DS, Conkright W, et al. Phase I clinical trial of a recombinant canarypoxvirus (ALVAC) vaccine expressing human carcinoembryonic antigen and the B7.1 co-stimulatory molecule. Cancer Immunol Immunother. 2000; 49(9):504-514. [PubMed: 11092617]

38. Weber JS, Hamid O, Chasalow SD, et al. Ipilimumab increases activated T cells and enhances humoral immunity in patients with advanced melanoma. J Immunother. 2012; 35(1):89-97. [PubMed: 22130166]

39. Hodi FS, O'Day SJ, McDermott DF, et al. Improved survival with ipilimumab in patients with metastatic melanoma. N Engl J Med. 2010; 363(8):711-723. [PubMed: 20525992]

40. Topalian SL, Hodi FS, Brahmer JR, et al. Safety, activity, and immune correlates of anti-PD-1 antibody in cancer. N Engl J Med. 2012; 366(26):2443-2454. [PubMed: 22658127]

41. Steinman RM. The dendritic cell system and its role in immunogenicity. Annu Rev Immunol. 1991; 9:271-296. [PubMed: 1910679]

42. Banchereau J, Palucka AK. Dendritic cells as therapeutic vaccines against cancer. Nat Rev Immunol. 2005; 5(4):296-306. [PubMed: 15803149]

43. Figdor CG, de Vries IJ, Lesterhuis WJ, et al. Dendritic cell immunotherapy: mapping the way. Nat Med. 2004; 10(5):475-480. [PubMed: 15122249]

44. Chang AE, Redman BG, Whitfield JR, et al. A phase I trial of tumor lysate-pulsed dendritic cells in the treatment of advanced cancer. Clin Cancer Res. 2002; 8(4):1021-1032. [PubMed: 11948109]

45. Tanaka F, Haraguchi N, Isikawa K, et al. Potential role of dendritic cell vaccination with MAGE peptides in gastrointestinal carcinomas. Oncol Rep. 2008; 20(5):1111-1116. [PubMed: 18949409]

46. Kantoff PW, Higano CS, Shore ND, et al. Sipuleucel-T immunotherapy for castration-resistant prostate cancer. N Engl J Med. 2010; 363(5):411-422. [PubMed: 20818862]

47. Rosenberg SA, Lotze MT, Muul LM, et al. A progress report on the treatment of 157 patients with advanced cancer using lymphokine-activated killer cells and interleukin-2 or high-dose interleukin-2 alone. N Engl J Med. 1987; 316(15):889-897. [PubMed: 3493432]

48. Besser MJ, Shapira-Frommer R, Treves AJ, et al. Clinical responses in a phase II study using adoptive transfer of short-term cultured tumor infiltration lymphocytes in metastatic melanoma patients. Clin Cancer Res. 2010; 16(9):2646-2655. [PubMed: 20406835]

49. Dudley ME, Rosenberg SA. Adoptive cell transfer therapy. Semin Oncol. 2007; 34(6):524-531. [PubMed: 18083376]

50. Dudley ME, Yang JC, Sherry R, et al. Adoptive cell therapy for patients with metastatic melanoma: evaluation of intensive myeloablative chemoradiation preparative regimens. J Clin Oncol. 2008; 26(32):5233-5239. [PubMed: 18809613]

51. Rosenberg SA, Yang JC, Sherry RM, et al. Durable complete responses in heavily pretreated patients with metastatic melanoma using T-cell transfer immunotherapy. Clin Cancer Res. 2011; 17(13):4550-4557. [PubMed: 21498393]

52. Amedei A, Niccolai E, D'Elios MM. T cells and adoptive immunotherapy: recent developments and future prospects in gastrointestinal oncology. Clin Dev Immunol. 2011; 2011:320571. [PubMed: 22110523]

53. Parkin DM, Bray F, Ferlay J, et al. Estimating the world cancer burden: Globocan 2000. Int J Cancer. 2001; 94(2):153-156. [PubMed: 11668491]

54. Center MM, Jemal A, Ward E. International trends in colorectal cancer incidence rates. Cancer Epidemiol Biomarkers Prev. 2009; 18(6):1688-1694. [PubMed: 19505900]

55. McLoughlin JM, Jensen EH, Malafa M. Resection of colorectal liver metastases: current perspectives. Cancer Control. 2006; 13(1):32-41. [PubMed: 16508624]

56. Labianca R, La Verde N, Garassino MC. Development and clinical indications of cetuximab. Int J Biol Markers. 2007; 22(1 suppl 4):S40-S46. [PubMed: 17520580]

57. Kurai J, Chikumi H, Hashimoto K, et al. Antibody-dependent cellular cytotoxicity mediated by cetuximab against lung cancer cell lines. Clin Cancer Res. 2007; 13(5):1552-1561. [PubMed: 17332301]

58. Cunningham D, Humblet Y, Siena S, et al. Cetuximab monotherapy and cetuximab plus irinotecan in irinotecan-refractory metastatic colorectal cancer. N Engl J Med. 2004; 351(4):337-345. [PubMed: 15269313] 
59. Hurwitz H, Fehrenbacher L, Novotny W, et al. Bevacizumab plus irinotecan, fluorouracil, and leucovorin for metastatic colorectal cancer. N Engl J Med. 2004; 350(23):2335-2342. [PubMed: 15175435]

60. Grothey A, Ellis LM. Targeting angiogenesis driven by vascular endothelial growth factors using antibody-based therapies. Cancer J. 2008; 14(3):170-177. [PubMed: 18536556]

61. Kabbinavar FF, Hambleton J, Mass RD, et al. Combined analysis of efficacy: the addition of bevacizumab to fluorouracil/leucovorin improves survival for patients with metastatic colorectal cancer. J Clin Oncol. 2005; 23(16):3706-3712. [PubMed: 15867200]

62. Schneider-Merck T, Lammerts van Bueren JJ, Berger S, et al. Human IgG2 antibodies against epidermal growth factor receptor effectively trigger antibody-dependent cellular cytotoxicity but, in contrast to IgG1, only by cells of myeloid lineage. J Immunol. 2010; 184(1):512-520. [PubMed: 19949082]

63. Van Cutsem E, Siena S, Humblet Y, et al. An open-label, single-arm study assessing safety and efficacy of panitumumab in patients with metastatic colorectal cancer refractory to standard chemotherapy. Ann Oncol. 2008; 19(1):92-98. [PubMed: 17785764]

64. Van Cutsem E, Peeters M, Siena S, et al. Open-label phase III trial of panitumumab plus best supportive care compared with best supportive care alone in patients with chemotherapy-refractory metastatic colorectal cancer. J Clin Oncol. 2007; 25(13):1658-1664. [PubMed: 17470858]

65. Douillard JY, Siena S, Cassidy J, et al. Randomized, phase III trial of panitumumab with infusional fluorouracil, leucovorin, and oxaliplatin (FOLF-OX4) versus FOLFOX4 alone as first-line treatment in patients with previously untreated metastatic colorectal cancer: the PRIME study. $\mathrm{J}$ Clin Oncol. 2010; 28(31):4697-4705. [PubMed: 20921465]

66. Brahmer JR, Drake CG, Wollner I, et al. Phase I study of single-agent anti-programmed death-1 (MDX-1106) in refractory solid tumors: safety, clinical activity, pharmacodynamics, and immunologic correlates. J Clin Oncol. 2010; 28(19):3167-3175. [PubMed: 20516446]

67. Smith RE, Colangelo L, Wieand HS, et al. Randomized trial of adjuvant therapy in colon carcinoma: 10-year results of NSABP protocol C-01. J Natl Cancer Inst. 2004; 96(15):1128-1132. [PubMed: 15292384]

68. Uyl-de Groot CA, Vermorken JB, Hanna MG Jr, et al. Immunotherapy with autologous tumor cellBCG vaccine in patients with colon cancer: a prospective study of medical and economic benefits. Vaccine. 2005; 23(17-18):2379-2387. [PubMed: 15755632]

69. Mosolits S, Ullenhag G, Mellstedt $\mathrm{H}$. Therapeutic vaccination in patients with gastrointestinal malignancies: a review of immunological and clinical results. Ann Oncol. 2005; 16(6):847-862. [PubMed: 15829493]

70. Hanna MG Jr, Hoover HC Jr, Vermorken JB, et al. Adjuvant active specific immunotherapy of stage II and stage III colon cancer with an autologous tumor cell vaccine: first randomized phase III trials show promise. Vaccine. 2001; 19(17-19):2576-2582. [PubMed: 11257395]

71. Schulze T, Kemmner W, Weitz J, et al. Efficiency of adjuvant active specific immunization with Newcastle disease virus modified tumor cells in colorectal cancer patients following resection of liver metastases: results of a prospective randomized trial. Cancer Immunol Immunother. 2009; 58(1):61-69. [PubMed: 18488223]

72. Liang W, Wang H, Sun TM, et al. Application of autologous tumor cell vaccine and NDV vaccine in treatment of tumors of digestive tract. World J Gastroenterol. 2003; 9(3):495-498. [PubMed: 12632504]

73. Morse MA, Deng Y, Coleman D, et al. A phase I study of active immunotherapy with carcinoembryonic antigen peptide (CAP-1)-pulsed, autologous human cultured dendritic cells in patients with metastatic malignancies expressing carcinoembryonic antigen. Clin Cancer Res. 1999; 5(6):1331-1338. [PubMed: 10389916]

74. Liu KJ, Wang CC, Chen LT, et al. Generation of carcinoembryonic antigen (CEA)-specific T-cell responses in HLA-A*0201 and HLA-A*2402 late-stage colorectal cancer patients after vaccination with dendritic cells loaded with CEA peptides. Clin Cancer Res. 2004; 10(8):26452651. [PubMed: 15102666] 
75. Lesterhuis WJ, de Vries IJ, Schuurhuis DH, et al. Vaccination of colorectal cancer patients with CEA-loaded dendritic cells: antigen-specific T cell responses in DTH skin tests. Ann Oncol. 2006; 17(6):974-980. [PubMed: 16600979]

76. Nair SK, Hull S, Coleman D, et al. Induction of carcinoembryonic antigen (CEA)-specific cytotoxic T-lymphocyte responses in vitro using autologous dendritic cells loaded with CEA peptide or CEA RNA in patients with metastatic malignancies expressing CEA. Int J Cancer. 1999; 82(1):121-124. [PubMed: 10360830]

77. Morse MA, Clay TM, Lyerly HK. CEA loaded dendritic cell vaccines. Cancer Chemother Biol Response Modif. 2002; 20:385-390. [PubMed: 12703216]

78. Laghi L, Bianchi P, Miranda E, et al. CD3+ cells at the invasive margin of deeply invading (pT3T4) colorectal cancer and risk of post-surgical metastasis: a longitudinal study. Lancet Oncol. 2009; 10(9):877-884. [PubMed: 19656725]

79. Gardini A, Ercolani G, Riccobon A, et al. Adjuvant, adoptive immunotherapy with tumor infiltrating lymphocytes plus interleukin-2 after radical hepatic resection for colorectal liver metastases: 5-year analysis. J Surg Oncol. 2004; 87(1):46-52. [PubMed: 15221919]

80. Karlsson M, Marits P, Dahl K, et al. Pilot study of sentinel-node-based adoptive immunotherapy in advanced colorectal cancer. Ann Surg Oncol. 2010; 17(7):1747-1757. [PubMed: 20119674]

81. Kamangar F, Dores GM, Anderson WF. Patterns of cancer incidence, mortality, and prevalence across five continents: defining priorities to reduce cancer disparities in different geographic regions of the world. J Clin Oncol. 2006; 24(14):2137-2150. [PubMed: 16682732]

82. Boonstra JJ, Kok TC, Wijnhoven BP, et al. Chemotherapy followed by surgery versus surgery alone in patients with resectable oesophageal squamous cell carcinoma: long-term results of a randomized controlled trial. BMC Cancer. 2011; 11:181. [PubMed: 21595951]

83. Wilkinson NW, Black JD, Roukhadze E, et al. Epidermal growth factor receptor expression correlates with histologic grade in resected esophageal adenocarcinoma. J Gastrointest Surg. 2004; 8(4):448-453. [PubMed: 15120370]

84. Ku GY, Ilson DH. Esophagogastric cancer: targeted agents. Cancer Treat Rev. 2010; 36(3):235248. [PubMed: 20122806]

85. De Vita F, Orditura M, Martinelli E, et al. A multicenter phase II study of induction chemotherapy with FOLFOX-4 and cetuximab followed by radiation and cetuximab in locally advanced oesophageal cancer. Br J Cancer. 2011; 104(3):427-432. [PubMed: 21245865]

86. Ruhstaller T, Pless M, Dietrich D, et al. Cetuximab in combination with chemoradiotherapy before surgery in patients with resectable, locally advanced esophageal carcinoma: a prospective, multicenter phase IB/II trial (SAKK 75/06). J Clin Oncol. 2011; 29(6):626-631. [PubMed: 21205757]

87. Safran H, Suntharalingam M, Dipetrillo T, et al. Cetuximab with concurrent chemoradiation for esophagogastric cancer: assessment of toxicity. Int J Radiat Oncol Biol Phys. 2008; 70(2):391395. [PubMed: 17980508]

88. Safran H, Dipetrillo T, Akerman P, et al. Phase I/II study of trastuzumab, paclitaxel, cisplatin and radiation for locally advanced, HER2 over-expressing, esophageal adenocarcinoma. Int J Radiat Oncol Biol Phys. 2007; 67(2):405-409. [PubMed: 17097832]

89. Chan JA, Blaszkowsky LS, Enzinger PC, et al. A multicenter phase II trial of single-agent cetuximab in advanced esophageal and gastric adenocarcinoma. Ann Oncol. 2011; 22(6):13671373. [PubMed: 21217058]

90. Gold PJ, Goldman B, Iqbal S, et al. Cetuximab as second-line therapy in patients with metastatic esophageal adenocarcinoma: a phase II South-west Oncology Group Study (S0415). J Thorac Oncol. 2010; 5(9):1472-1476. [PubMed: 20631636]

91. Lordick F, Luber B, Lorenzen S, et al. Cetuximab plus oxaliplatin/ leucovorin/5-fluorouracil in first-line metastatic gastric cancer: a phase II study of the Arbeitsgemeinschaft Internistische Onkologie (AIO). Br J Cancer. 2010; 102(3):500-505. [PubMed: 20068568]

92. Pinto C, Di Fabio F, Barone C, et al. Phase II study of cetuximab in combination with cisplatin and docetaxel in patients with untreated advanced gastric or gastro-oesophageal junction adenocarcinoma (DOCETUX study). Br J Cancer. 2009; 101(8):1261-1268. [PubMed: 19773760] 
93. Han SW, Oh DY, Im SA, et al. Phase II study and biomarker analysis of cetuximab combined with modified FOLFOX6 in advanced gastric cancer. Br J Cancer. 2009; 100(2):298-304. [PubMed: 19127259]

94. Lorenzen S, Schuster T, Porschen R, et al. Cetuximab plus cisplatin-5-fluorouracil versus cisplatin-5-fluorouracil alone in first-line metastatic squamous cell carcinoma of the esophagus: a randomized phase II study of the Arbeitsgemeinschaft Internistische Onkologie. Ann Oncol. 2009; 20(10):1667-1673. [PubMed: 19549707]

95. Pinto C, Di Fabio F, Siena S, et al. Phase II study of cetuximab in combination with FOLFIRI in patients with untreated advanced gastric or gastroesophageal junction adenocarcinoma (FOLCETUX study). Ann Oncol. 2007; 18(3):510-517. [PubMed: 17164226]

96. Kono K, Mizukami Y, Daigo Y, et al. Vaccination with multiple peptides derived from novel cancer-testis antigens can induce specific T-cell responses and clinical responses in advanced esophageal cancer. Cancer Sci. 2009; 100(8):1502-1509. [PubMed: 19459850]

97. Toh U, Yamana H, Sueyoshi S, et al. Locoregional cellular immunotherapy for patients with advanced esophageal cancer. Clin Cancer Res. 2000; 6(12):4663-4673. [PubMed: 11156218]

98. Toh U, Sudo T, Kido K, et al. Locoregional adoptive immunotherapy resulted in regression in distant metastases of a recurrent esophageal cancer. Int J Clin Oncol. 2002; 7(6):372-375. [PubMed: 12494255]

99. Crew KD, Neugut AI. Epidemiology of gastric cancer. World J Gastroenterol. 2006; 12(3):354362. [PubMed: 16489633]

100. Paoletti X, Oba K, Burzykowski T, et al. Benefit of adjuvant chemotherapy for resectable gastric cancer: a meta-analysis. JAMA. 2010; 303(17):1729-1737. [PubMed: 20442389]

101. Ohtsu A, Shah MA, Van Cutsem E, et al. Bevacizumab in combination with chemotherapy as first-line therapy in advanced gastric cancer: a randomized, double-blind, placebo-controlled phase III study. J Clin Oncol. 2011; 29(30):3968-3976. [PubMed: 21844504]

102. Reddy D, Wainberg ZA. Targeted therapies for metastatic esophagogastric cancer. Curr Treat Options Oncol. 2011; 12(1):46-60. [PubMed: 21298375]

103. Bang YJ, Van Cutsem E, Feyereislova A, et al. Trastuzumab in combination with chemotherapy versus chemotherapy alone for treatment of HER2-positive advanced gastric or gastrooesophageal junction cancer (ToGA): a phase 3, open-label, randomised controlled trial. Lancet. 2010; 376(9742):687-697. [PubMed: 20728210]

104. Kono K, Takahashi A, Sugai H, et al. Dendritic cells pulsed with HER-2/neu-derived peptides can induce specific T-cell responses in patients with gastric cancer. Clin Cancer Res. 2002; 8(11): 3394-3400. [PubMed: 12429626]

105. Jiang JT, Shen YP, Wu CP, et al. Increasing the frequency of CIK cells adoptive immunotherapy may decrease risk of death in gastric cancer patients. World J Gastroenterol. 2010; 16(48):61556162. [PubMed: 21182234]

106. Kono K, Takahashi A, Ichihara F, et al. Prognostic significance of adoptive immunotherapy with tumor-associated lymphocytes in patients with advanced gastric cancer: a randomized trial. Clin Cancer Res. 2002; 8(6):1767-1771. [PubMed: 12060615]

107. Venook AP, Papandreou C, Furuse J, de Guevara LL. The incidence and epidemiology of hepatocellular carcinoma: a global and regional perspective. Oncologist. 2010; 15(suppl 4):5-13. [PubMed: 21115576]

108. El-Serag HB. Hepatocellular carcinoma. N Engl J Med. 2011; 365(12):1118-1127. [PubMed: 21992124]

109. Mannelli L, Kim S, Hajdu CH, et al. Assessment of tumor necrosis of hepatocellular carcinoma after chemoembolization: diffusion-weighted and contrast-enhanced MRI with histopathologic correlation of the explanted liver. AJR Am J Roentgenol. 2009; 193(4):1044-1052. [PubMed: 19770328]

110. Thomas MB, Morris JS, Chadha R, et al. Phase II trial of the combination of bevacizumab and erlotinib in patients who have advanced hepatocellular carcinoma. J Clin Oncol. 2009; 27(6): 843-850. [PubMed: 19139433] 
111. Butterfield LH, Ribas A, Dissette VB, et al. A phase I/II trial testing immunization of hepatocellular carcinoma patients with dendritic cells pulsed with four alpha-fetoprotein peptides. Clin Cancer Res. 2006; 12(9):2817-2825. [PubMed: 16675576]

112. Lee WC, Wang HC, Hung CF, et al. Vaccination of advanced hepatocellular carcinoma patients with tumor lysate-pulsed dendritic cells: a clinical trial. J Immunother. 2005; 28(5):496-504. [PubMed: 16113606]

113. Palmer DH, Midgley RS, Mirza N, et al. A phase II study of adoptive immunotherapy using dendritic cells pulsed with tumor lysate in patients with hepatocellular carcinoma. Hepatology. 2009; 49(1):124-132. [PubMed: 18980227]

114. Chi KH, Liu SJ, Li CP, et al. Combination of conformal radiotherapy and intratumoral injection of adoptive dendritic cell immunotherapy in refractory hepatoma. J Immunother. 2005; 28(2): 129-135. [PubMed: 15725956]

115. Kuang M, Peng BG, Lu MD, et al. Phase II randomized trial of autologous formalin-fixed tumor vaccine for postsurgical recurrence of hepatocellular carcinoma. Clin Cancer Res. 2004; 10(5): 1574-1579. [PubMed: 15014006]

116. Peng B, Liang L, Chen Z, et al. Autologous tumor vaccine lowering postsurgical recurrent rate of hepatocellular carcinoma. Hepatogastroenterology. 2006; 53(69):409-414. [PubMed: 16795983]

117. Une Y, Kawata A, Uchino J. [Adopted immunochemotherapy using IL-2 and spleen LAK cellrandomized study]. Nihon Geka Gakkai Zasshi. 1991; 92(9):1330-1333. [PubMed: 1658591]

118. Wang Y, Chen H, Wu M, et al. Postoperative immunotherapy for patients with hepatocarcinoma using tumor-infiltrating lymphocytes. Chin Med J (Engl). 1997; 110(2):114-117. [PubMed: 9594281]

119. Henne-Bruns D, Vogel I, Lüttges J, et al. Ductal adenocarcinoma of the pancreas head: survival after regional versus extended lymphadenectomy. Hepatogastroenterology. 1998; 45(21):855866. [PubMed: 9684147]

120. Johnson CD, Schwall G, Flechtenmacher J, et al. Resection for adenocarcinoma of the body and tail of the pancreas. Br J Surg. 1993; 80(9):1177-1179. [PubMed: 8402126]

121. Mukaiya M, Hirata K, Satoh T, et al. Lack of survival benefit of extended lymph node dissection for ductal adenocarcinoma of the head of the pancreas: retrospective multi-institutional analysis in Japan. World J Surg. 1998; 22(3):248-253. [PubMed: 9494416]

122. Cleary SP, Gryfe R, Guindi M, et al. Prognostic factors in resected pancreatic adenocarcinoma: analysis of actual 5-year survivors. J Am Coll Surg. 2004; 198(5):722-731. [PubMed: 15110805]

123. Hernandez J, Mullinax J, Clark W, et al. Survival after pancreaticoduodenectomy is not improved by extending resections to achieve negative margins. Ann Surg. 2009; 250(1):76-80. [PubMed: 19561479]

124. Raut CP, Tseng JF, Sun CC, et al. Impact of resection status on pattern of failure and survival after pancreaticoduodenectomy for pancreatic adenocarcinoma. Ann Surg. 2007; 246(1):52-60. [PubMed: 17592291]

125. Toomey P, Hernandez J, Morton C, et al. Resection of portovenous structures to obtain microscopically negative margins during pancreaticoduodenectomy for pancreatic adenocarcinoma is worthwhile. Am Surg. 2009; 75(9):804-810. [PubMed: 19774952]

126. Helm JF, Centeno BA, Coppola D, et al. Outcomes following resection of pancreatic adenocarcinoma: 20-year experience at a single institution. Cancer Control. 2008; 15(4):288294. [PubMed: 18813196]

127. Toomey P, Hernandez J, Golkar F, et al. Pancreatic adenocarcinoma: complete tumor extirpation improves survival benefit despite larger tumors for patients who undergo distal pancreatectomy and splenectomy. J Gastrointest Surg. 2012; 16(2):376-381. [PubMed: 22135126]

128. Varadhachary GR, Tamm EP, Abbruzzese JL, et al. Borderline resectable pancreatic cancer: definitions, management, and role of preoperative therapy. Ann Surg Oncol. 2006; 13(8):10351046. [PubMed: 16865597]

129. Conroy T, Desseigne F, Ychou M, et al. FOLFIRINOX versus gemcitabine for metastatic pancreatic cancer. N Engl J Med. 2011; 364(19):1817-1825. [PubMed: 21561347]

130. Philip PA, Benedetti J, Corless CL, et al. Phase III study comparing gemcitabine plus cetuximab versus gemcitabine in patients with advanced pancreatic adenocarcinoma: Southwest Oncology 
Group-directed intergroup trial S0205. J Clin Oncol. 2010; 28(22):3605-3610. [PubMed: 20606093]

131. Kindler HL, Niedzwiecki D, Hollis D, et al. Gemcitabine plus bevacizumab compared with gemcitabine plus placebo in patients with advanced pancreatic cancer: phase III trial of the Cancer and Leukemia Group B (CAL-GB 80303). J Clin Oncol. 2010; 28(22):3617-3622. [PubMed: 20606091]

132. Royal RE, Levy C, Turner K, et al. Phase 2 trial of single agent ipilimumab (anti-CTLA-4) for locally advanced or metastatic pancreatic adenocarcinoma. J Immunother. 2010; 33(8):828-833. [PubMed: 20842054]

133. Beatty GL, Chiorean EG, Fishman MP, et al. CD40 agonists alter tumor stroma and show efficacy against pancreatic carcinoma in mice and humans. Science. 2011; 331(6024):16121616. [PubMed: 21436454]

134. Lutz E, Yeo CJ, Lillemoe KD, et al. A lethally irradiated allogeneic granulocyte-macrophage colony stimulating factor-secreting tumor vaccine for pancreatic adenocarcinoma: a phase II trial of safety, efficacy, and immune activation. Ann Surg. 2011; 253(2):328-335. [PubMed: 21217520]

135. Jaffee EM, Hruban RH, Biedrzycki B, et al. Novel allogeneic granulocyte-macrophage colonystimulating factor-secreting tumor vaccine for pancreatic cancer: a phase I trial of safety and immune activation. J Clin Oncol. 2001; 19(1):145-156. [PubMed: 11134207]

136. Hardacre JM, Mulcahy MF, Small W Jr, et al. Effect of the addition of algenpantucel-L immunotherapy to standard adjuvant therapy on survival in patients with resected pancreas cancer. J Clin Oncol (ASCO Gastrointestinal Cancers Symposium). 2011; 29:236.

137. Mulé JJ. Dendritic cell-based vaccines for pancreatic cancer and melanoma. Ann N Y Acad Sci. 2009; 1174:33-40. [PubMed: 19769734]

138. Fukunaga A, Miyamoto M, Cho Y, et al. CD8+ tumor-infiltrating lymphocytes together with CD4+ tumor-infiltrating lymphocytes and dendritic cells improve the prognosis of patients with pancreatic adenocarcinoma. Pancreas. 2004; 28(1):e26-e31. [PubMed: 14707745]

139. Kawaoka T, Oka M, Takashima M, et al. Adoptive immunotherapy for pancreatic cancer: cytotoxic T lymphocytes stimulated by the MUC1-expressing human pancreatic cancer cell line YPK-1. Oncol Rep. 2008; 20(1):155-163. [PubMed: 18575732]

140. Kondo H, Hazama S, Kawaoka T, et al. Adoptive immunotherapy for pancreatic cancer using MUC1 peptide-pulsed dendritic cells and activated T lymphocytes. Anticancer Res. 2008; 28(1B):379-387. [PubMed: 18383873] 


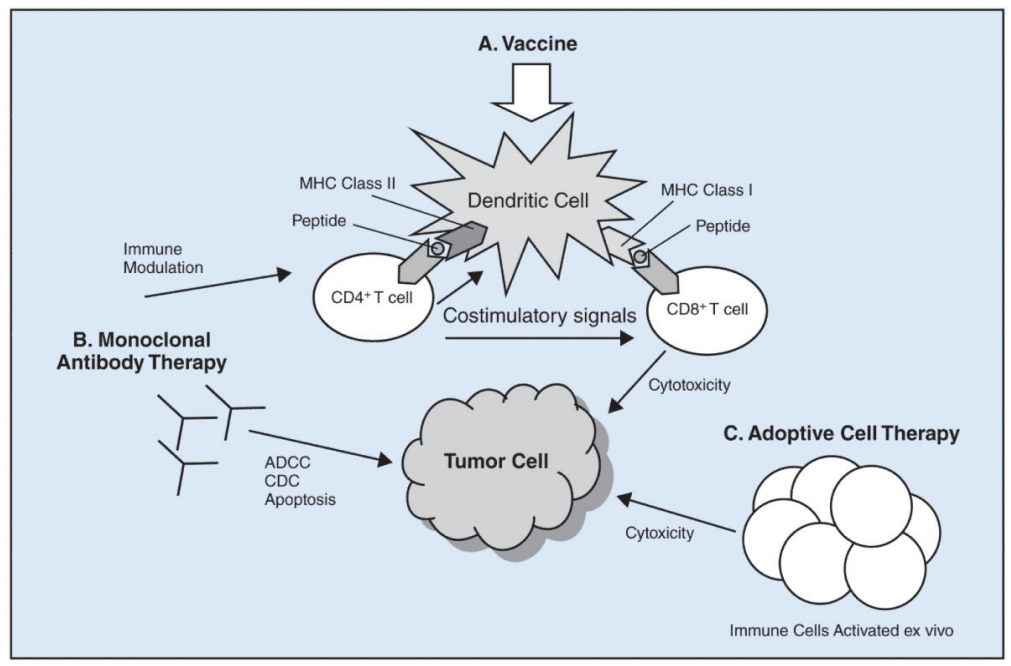

Figure.

Immunotherapeutic strategies. (A) Vaccine-based immunotherapy. Vaccination leads to the presentation of peptides on major histocompatibility complex (MHC) classes I and II molecules of antigen-presenting cells, such as dendritic cells (DCs), to stimulate antitumor $\mathrm{CD}^{+}$and $\mathrm{CD}^{+}{ }^{+} \mathrm{T}$ cells, respectively. Activated $\mathrm{CD} 4^{+} \mathrm{T}$ cells send costimulatory signals to induce full maturation of DCs and activation of $\mathrm{CD}^{+} \mathrm{T}$ cells. Activated $\mathrm{CD} 8^{+} \mathrm{T}$ cells migrate to the site of tumor and mediate tumor killing. (B) Monoclonal antibody therapy. Injection of monoclonal antibodies leads to antibody-dependent cellular cytotoxicity (ADCC), complement-mediated cytotoxicity (CDC), or apoptosis by blockade of required growth factors and signals. Alternatively, monoclonal antibodies bind to immune cells to enhance immune responses. (C) Adoptive cell therapy. Immune cells isolated from the peripheral blood, tumor, and/or lymph nodes are activated in vitro with high-dose interleukin-2 (IL-2). High numbers of activated immune cells are injected back into the patient to mediate tumor cell cytotoxicity. 
Table 1

Commonly Targeted Tumor-Associated Antigens Expressed in Gastrointestinal (GI) Cancers

\begin{tabular}{|c|c|c|c|}
\hline Type & Example & $\begin{array}{l}\text { GI Tumor } \\
\text { Involved }\end{array}$ & Study \\
\hline $\begin{array}{l}\text { Cancer testis } \\
\text { antigen }\end{array}$ & $\begin{array}{l}\text { MAGE-A3/4 } \\
\text { NY-ESO-1 }\end{array}$ & Esophageal & $\begin{array}{l}\text { Bujas et } \mathrm{al}^{24} \\
\text { Forghanifard et } \mathrm{al}^{25}\end{array}$ \\
\hline $\begin{array}{l}\text { Overexpressed } \\
\text { self-antigen }\end{array}$ & $\begin{array}{l}\text { HER2 } \\
\text { MUC1 } \\
\text { Mesothelin }\end{array}$ & $\begin{array}{l}\text { Gastric } \\
\text { Pancreatic } \\
\text { Pancreatic }\end{array}$ & 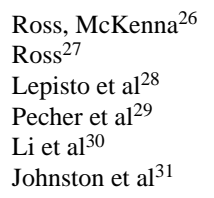 \\
\hline $\begin{array}{l}\text { Oncofetal } \\
\text { antigen }\end{array}$ & $\begin{array}{l}\text { AFP } \\
\text { CEA }\end{array}$ & $\begin{array}{l}\text { Hepatocellular } \\
\text { Colorectal }\end{array}$ & $\begin{array}{l}\text { Butterfield }{ }^{32} \\
\text { Evdokimova, } \\
\text { Butterfield }^{33} \\
\text { Conry et al }^{34} \\
\text { Marshall et al }{ }^{35} \\
\text { Kaufman et a }{ }^{36} \\
\text { Hörig et al }{ }^{37}\end{array}$ \\
\hline
\end{tabular}

$\mathrm{AFP}=$ alpha-fetoprotein, $\mathrm{CEA}=$ carcinoembryonic antigen, HER2 $=$ human epidermal growth factor receptor $2, \mathrm{MUC} 1=$ mucin- 1. 
Table 2

FDA-Approved Monoclonal Antibodies for Use in Gastroesophageal Cancers

\begin{tabular}{|c|c|c|c|}
\hline Drug & Target & $\begin{array}{l}\text { Year of } \\
\text { FDA Approval }\end{array}$ & Indication \\
\hline \multirow{2}{*}{ Cetuximab } & \multirow{2}{*}{ EGFR } & 2004 & $\begin{array}{l}\text { First-line therapy for EGFR-expressing metastatic colorectal cancer in combination with } \\
\text { irinotecan in patients whose disease is refractory to irinotecan-based chemotherapy }\end{array}$ \\
\hline & & 2007 & $\begin{array}{l}\text { Monotherapy for patients with EGFR-expressing metastatic colorectal cancer after failure of } \\
\text { both irinotecan and oxaliplatin-based chemotherapy regimens }\end{array}$ \\
\hline \multirow{2}{*}{ Bevacizumab } & \multirow{2}{*}{ VEGF } & 2004 & First-line therapy for metastatic colorectal cancer in combination with FOLFIRI therapy \\
\hline & & 2006 & Second-line therapy for metastatic colorectal cancer in combination with FOLFOX therapy \\
\hline Panitumumab & EGFR & 2006 & $\begin{array}{l}\text { First-line therapy for EGFR-expressing metastatic colorectal carcinoma in combination with } \\
\text { FOLFIRI therapy }\end{array}$ \\
\hline Trastuzumab & HER2 & 2010 & $\begin{array}{l}\text { First- or second-line therapy for HER2-positive metastatic gastric or gastroesophageal } \\
\text { adenocarcinoma in combination with cisplatin and a fluoropyrimidine }\end{array}$ \\
\hline
\end{tabular}

EGFR $=$ epidermal growth factor receptor, FOLFIRI $=5$-fluorouracil, leucovorin, irinotecan, FOLFOX $=5$-fluorouracil, leucovorin, oxaliplatin, HER2 = human epidermal growth factorreceptor 2, VEGF = vascular endothelial growth factor. 
Table 3

Phase II Clinical Trials for Patients Undergoing Neoadjuvant Monoclonal Antibody Therapy With Chemotherapy \pm Radiation Therapy

\begin{tabular}{|l|c|c|c|c|c|l|}
\hline Therapy & Pathology & $\begin{array}{c}\text { No. of } \\
\text { Patients }\end{array}$ & $\begin{array}{c}\text { No. of } \\
\text { Partial } \\
\text { Responses }\end{array}$ & $\begin{array}{c}\text { No. of } \\
\text { Complete } \\
\text { Responses }\end{array}$ & $\begin{array}{c}\text { Median } \\
\text { Survival } \\
\text { (mos) }\end{array}$ & \multicolumn{1}{|c|}{ Study } \\
\hline Cetuximab + FOLFOX/RT + surgery & E, ESCC & 41 & 12 & 8 & 17 & De Vita et al ${ }^{85}$ \\
\hline $\begin{array}{l}\text { Cetuximab + cisplatin/docetaxel/RT + } \\
\text { surgery }\end{array}$ & E, ESCC & 28 & 10 & 9 & NA & Ruhstaller et al $^{86}$ \\
\hline $\begin{array}{l}\text { Cetuximab + carboplatin/paclitaxel/RT } \\
\pm \text { surgery }\end{array}$ & E, G, ESCC & 60 & NA & 13 & NA & Safran et al ${ }^{87}$ \\
\hline $\begin{array}{l}\text { Trastuzumab + paclitaxel/cisplatin/RT } \\
\text { + surgery }\end{array}$ & E (HER2+) & 19 & 1 & 3 & 24 & Safran et al ${ }^{88}$ \\
\hline
\end{tabular}

$\mathrm{E}=$ esophageal adenocarcinoma, $\mathrm{ESCC}=$ esophageal squamous cell carcinoma, FOLFOX $=$ 5-fluorouracil, leucovorin, oxaliplatin, $\mathrm{G}=$ gastric adenocarcinoma, HER2 = human epidermal growth factor receptor $2, \mathrm{NA}=$ not available, $\mathrm{RT}=$ radiation therapy. 


\section{Table 4}

Phase I or II Clinical Trials of Monoclonal Antibody Therapy for Patients With Metastatic Esophageal, Gastroesophageal, and Gastric Cancers

\begin{tabular}{|l|c|c|c|c|c|l|}
\hline Therapy & Pathology & $\begin{array}{c}\text { No. of } \\
\text { Patients }\end{array}$ & $\begin{array}{c}\text { No. of } \\
\text { Partial } \\
\text { Responses }\end{array}$ & $\begin{array}{c}\text { No. of } \\
\text { Complete } \\
\text { Responses }\end{array}$ & $\begin{array}{c}\text { Median } \\
\text { Survival } \\
\text { (mos) }\end{array}$ & \multicolumn{1}{|c|}{ Study } \\
\hline Cetuximab & E, GEJ, G & 35 & 1 & 0 & 3.1 & Chan et al $^{89}$ \\
\hline Cetuximab & E, GEJ & 55 & 3 & 0 & 4.0 & Gold et al $^{90}$ \\
\hline Cetuximab + FOLFOX & GEJ, G & 52 & 26 & 4 & 9.5 & Lordick et al $^{91}$ \\
\hline Cetuximab + cisplatin/docetaxel & GEJ, G & 72 & 27 & 1 & 9.0 & Pinto et al $^{92}$ \\
\hline Cetuximab + FOLFOX & G & 40 & 21 & 0 & 9.9 & Han et al ${ }^{93}$ \\
\hline $\begin{array}{l}\text { Cetuximab + 5-FU/cisplatin vs } \\
\text { 5-FU/cisplatin }\end{array}$ & ESCC & 32 vs 30 & 11 vs 8 & 0 vs 1 & 9.5 vs 5.5 & Lorenzen et al ${ }^{94}$ \\
\hline Cetuximab + FOLFIRI & GEJ, G & 38 & 11 & 4 & 16 & Pinto et al ${ }^{95}$ \\
\hline
\end{tabular}

$\mathrm{E}=$ esophageal adenocarcinoma, $\mathrm{ESCC}=$ esophageal squamous cell carcinoma, FOLFOX $=5$-fluorouracil, leucovorin, oxaliplatin, FOLFIRI $=5$ fluorouracil, leucovorin, irinotecan, 5-FU = 5-fluorouracil, $\mathrm{G}=$ gastric adenocarcinoma, $\mathrm{GEJ}=$ gastroesophageal junction adenocarcinoma, $\mathrm{NA}=$ not available. 